\title{
The Role of Vagal Nerve Root Injury on Respiration Disturbances in Subarachnoid Hemorrhage
}

\author{
Subaraknoid Kanamada Solunum Bozuklukları Oluşmasında Vagal \\ Sinir Kökü Hasarmm Rolü
}

Murteza CAKIR ${ }^{1}$, Canan ATALAY², Zeynep CAKIR 3 , Mucahit EMET², Mehmet Dumlu AYDIN ${ }^{1}$, Nazan AYDIN4, Arif ONDER ${ }^{5}$ Muhammed CALIK

${ }_{1}^{1}$ Ataturk University, School of Medicine, Department of Neurosurgery, Erzurum, Turkey

${ }^{2}$ Ataturk University, School of Medicine, Department of Anesthesiology and Reanimation, Erzurum, Turkey

${ }^{3}$ Ataturk University, School of Medicine, Department of Emergency Medicine, Erzurum, Turkey

${ }^{4}$ Ataturk University, School of Medicine, Department of Psychiatry, Erzurum, Turkey

${ }_{5}^{5}$ vrasya Hospital, Department of Neurosurgery, Istanbul, Turkey

${ }^{6}$ Ataturk University, School of Medicine, Department of Pathology, Erzurum, Turkey

Corresponding Author: Murteza CAKIR / E-mail: m.ckr28@hotmail.com

\begin{abstract}
AIM: We examined whether there is a relationship between vagal nerve root injury and the severity of respiration disorders associated with subarachnoid hemorrhage (SAH).

MATERIAL and METHODS: This study was conducted on 20 rabbits. Experimental SAH was induced by injecting homologous blood into the cisterna magna. During the experiment, electrocardiography and respiratory rhythms were measured daily. After the experiment, any axonal injury or changes to the arterial nervorums of the vagal nerves were examined. All respiratory irregularities and vagal nerve degenerations were statistically analyzed.

RESULTS: Normal respiration rate, as measured in the control group, was $30 \pm 6 \mathrm{bpm}$. In the SAH-induced group, respiration rates were initially $20 \pm 4 \mathrm{bpm}$, increasing to $40 \pm 9 / \mathrm{min}$ approximately ten hours later, with severe tachypneic and apneic variation. In histopathological examinations, axon density of vagal nerves was $28500 \pm 5500$ in both control and sham animals, whereas axon density was $22250 \pm 3500$ in survivors and $16450 \pm 2750$ in dead SAH animals. The severity of axonal degeneration of vagal nerves was greater in the six dead animals than in the survivors.
\end{abstract}

CONCLUSION: If vagal nerves are lesioned, the muscles of respiration are paralyzed and respiratory reflexes are disrupted. That the ischemic and mechanical factors created by SAH cause vagal nerve root injury and respiration disorders may be inevitable and fatal.

KEYWORDS: Injury, Respiration, Rabbit, Subarachnoid hemorrhage, Vagal nerve

öz

AMAÇ: Subaraknoid kanamada (SAK) solunum bozukluklarının şiddetiyle vagal sinir kökü hasarı arasında bir ilişki olup olmadığını inceledik. YÖNTEM ve GEREÇLER: Çalışma 20 tavşanda gerçekleştirildi. Sisterna magnaya homolog kan enjeksiyonuyla deneysel SAK oluşturuldu. Deney sırasında günlük olarak elektrokardiyografi ve solunum ritimleri ölçümü yapıldı. Deneyden sonra, vagal sinirlerin arteriyel nervorumlarındaki değişiklikler ve varsa aksonal hasar incelendi. Tüm solunum düzensizlikleri ve vagal sinir dejenerasyonları istatistiksel olarak analiz edildi.

BULGULAR: Kontrol grubunda ölçüldüğü şekilde normal solunum hızı $30 \pm 6 \mathrm{dk}$ şeklindeydi. SAK indüklenmiş grupta solunum hızları başlangıçta $20 \pm 4$ dk iken, on saat sonrasında şiddetli takipneik ve apneik varyasyonla $40 \pm 9 / \mathrm{dk}$ değerine yükseldi. Histopatolojik incelemelerde vagal sinirlerin akson yoğunluğu hem kontrol hem taklit (sham) deneklerinde $28500 \pm 5500$ iken yaşayan SAK deneklerinde $22250 \pm 3500$ ve ölü SAK deneklerinde $16450 \pm 2750$ bulundu. Vagal sinirlerde aksonal dejenerasyonun şiddeti 6 ölü denekte yaşayanlardan daha fazlaydı.

SONUÇ: Vagal sinirlerde lezyon oluşursa, solunum kasları felce uğrar ve solunum refleksleri bozulur. SAK'nın oluşturduğu iskemik ve mekanik faktörlerin vagal sinir kök hasarı ve solunum bozuklukları oluşturması kaçınılmaz ve ölümcül olabilir.

ANAHTAR SÖZCÜKLER: Hasar, Solunum, Tavşan, Subaraknoid kanama, Vagal sinir

\section{INTRODUCTION}

Respiration can be defined as a process of gas exchange in the lungs via inspiratory and expiratory drives $(7,21)$. Respiratory organs are innervated by somatic and autonomic nervous systems (24). The somatic sensitive-motor nerves arise from the lower brainstem, cervical and thoracic segments and surround the respiration muscles, pleural and thoracic surfaces, and play a major role in the conscious continuation of respiration (21). Autonomic nerves control the caliber of the conducting airways, pulmonary blood vessels, the volume 
of respiratory units, the activity of bronchial glands and respiration reflexes. The vagal nerve is the principle neural pathway that interconnects the brainstem and the lungs. It is involved in maintaining the rhythm of central respiration, and regulation of the pulmonary vasculature, airways and pulmonary secretion (8). Activation of the pulmonary stretch receptors by lung inflation or vagal stimulation evokes the Hering-Breuer reflex, which is characterized by inspiratory inhibition and expiratory prolongation (13). Stimulation of the vagal nerve can cause bronchoconstriction, respiration rhythm disorders and apneustic attacks (18). When respiration units are deformed by chemical, pathophysiologic or mechanical factors, these neural networks initiate the HeringBreuer reflex and affect the pattern of breathing $(16,19)$. So, ischemic vagal discharges resembling vagal stimulation may be considered a triggering factor in apneustic attacks at the beginning of subarachnoid hemorrhage (SAH). The immunoregulatory role of the vagal nerve on the lungs may be damaged secondary to vagal nerve injury, and respiratory rhythm may be disrupted due to lung inflammation (9).

Vagal nerve injury can cause laryngopharyngeal muscle paralysis, tracheobronchial distortions, reflex vagal bradycardia and bradypnea (22). In late phase $\mathrm{SAH}$, irreversible axonal injury may mimic a blockade of the vagal nerves. The HeringBreuer reflex may be abolished during acutely developed cerebral ischemia and restored by recovery of ischemic cerebral processes $(1,20)$. It is well known that axon density of vagal nerves plays an important role in their activities (14). Also, neuron density of autonomic ganglions strongly affects autonomic functions (14). So, axon density of vagal nerves may be an important factor in the regulation of respiration, and reduced neuron density due to $\mathrm{SAH}$ may cause respiration disorders and even arrest. In the presented study, it is demonstrated that SAH causes not only cerebral ischemic insult, but also brain stem and cranial nerve injuries. We hypothesized that ischemic vagal nerve root injury is an important factor in the development of respiratory arrhythmia; a novel concept not previously studied.

\section{MATERIAL and METHODS}

This study was conducted at the Medical Experimental Research Center, Ataturk University. The Ethical Committee of Ataturk University approved the study protocol. All procedures were performed in accordance with the National Institute of Health Principles of Laboratory Animal Care. A total of twenty hybrid rabbits aged two years and weighing $3.5 \pm 025 \mathrm{~kg}$ were used. Four rabbits $(n=4)$ were determined as a control group and were not subjected to surgery. The remaining animals $(n=16)$ were divided into two groups; $\mathrm{SAH}$ group subjected to artificial subarachnoid hemorrhage $(n=10)$ and a SHAM group subjected to a similar surgical procedure without inducing $\mathrm{SAH}(\mathrm{n}=6)$. Animals were fasted for 6 hours prior to surgery. A balanced injectable anesthesia was used for reducing pain and mortality. After inducing anesthesia with isoflurane administered via a facemask, $0.2 \mathrm{~mL} / \mathrm{kg}$ of the anesthetic combination (Ketamine $\mathrm{HCL}, 150 \mathrm{mg} / 1.5 \mathrm{~mL}$;
Xylazine $\mathrm{HCL}, 30 \mathrm{mg} / 1.5 \mathrm{~mL}$; and distilled water, $1 \mathrm{~mL}$ ) was subcutaneously injected immediately before surgery. All animals were monitored for electrocardiographic changes, respiration patterns, and blood oxygen concentrations during the procedures. All parameters were recorded by Sony camera and were analyzed by physicians who were blinded to study. During the operation, $0.1 \mathrm{~mL} / \mathrm{kg}$ of anesthetic combination was used as required. For the SAH group, $0.75 \mathrm{~mL}$ of autologous blood was taken from the auricular artery and injected into the cisterna magna via a 22-gauge hypodermic needle over approximately one minute. For the SHAM group, $0.75 \mathrm{~mL}$ of isotonic saline solution was injected instead of blood. Six of the ten rabbits subjected to experimental SAH died within the first week post-surgery and the surviving four were followed for 20 days without any medical treatment and then sacrificed. At that point, the lungs and all vagal nerves just over the jugular foramen were removed for histology examination. Tissues were kept in a $10 \%$ formalin solution for 7 days, following which $1 \mu \mathrm{m}$ tissue sections were taken and stained with S-100. For the purpose of this study, Schwann cell body necrosis and degenerated axon numbers were the injury criteria of vagal nerves.

To estimate the total number of axons of vagal nerves, the fractionation technique was used after the cross-sections of the vagal nerves were obtained according to the basic sampling procedure and stereological principles described by Gundersen (10). Axon density of the vagal nerve was estimated using an unbiased counting frame of known size. The microscope used had a two attachments; a camera and was and a platform with two dial indicators and two arms for mounting the microscope stage. The two dial indicators $(5 \mu \mathrm{m}$ resolution) mounted to the microscope measured movement in the $x$ and $y$ planes of the stage. The vagal nerve images and measurements obtained were recorded by the camera and uploaded to a computer and the numbers of living and degenerated neurons of the vagal nerve of all animals were counted.

In order to estimate respiration capacities and depth, respiration-time curves generated by computer were overlaid onto minisquare pointed papers in order to facilitate calculations (See Figure 3 for an example). The height of the curve from the basal line to the apical points was accepted as respiration depth and the surface area under the curve was accepted as respiration capacity per respiration cyclus recorded over a period of two seconds. Then, these values were multiplied by 30 in order to calculate mean values per minute.

Numbers of degenerated vagal nerve root axons, respiration depths and respiration capacity values were compared between the three groups using the Mann-Whitney $U$ test.

\section{RESULTS}

Six of the SAH-induced animals and one of the SHAM group animals died within the first 7 days post-surgery due to respiration arrest, and the remaining animals $(n=4$ of $S A H ; n=3$ of SHAM) were followed for a total of 20 days post-surgery. 
Clinically, signs of meningeal irritation, unconsciousness, convulsive attacks, fever, apnea, cardiac arrhythmia and breath disturbances were observed frequently in premortal periods of all of the animals who expired within the first week post-surgery and three of the animals who survived for the full 20 days.

In normal animals, cardiac pulse was $250 \pm 30 \mathrm{bpm}$; breath pulse was $30 \pm 7 \mathrm{bpm}$ and blood oxygen concentration was $95 \pm 5 \%$. In the early stages of induced $\mathrm{SAH}$, cardiac rhythm decreased to $140 \pm 40 \mathrm{bpm}$; breath pulse to $15 \pm 5 \mathrm{bpm}$ and blood oxygen concentration to $70 \pm 10 \%$. A considerable electrocardiographic change was observed as ST depression, ventricular extrasystoles, bigeminal pulses, QRS separation and fibrillations. However, in the late stages of mortal $\mathrm{SAH}$, cardiac pulse increased to $330 \pm 30 \mathrm{bpm}$. Initially, respiration rates were $20 \pm 4 \mathrm{bpm}$; about ten hours later respiration increased to $40 \pm 9 \mathrm{bpm}$ with severe tachypneic and apneic variation. In the analyses of respiration parameters, decreases in respiration frequency (bradypnea) (15 \pm 5$)$ and increases respiration amplitude (30\%) were observed during the first few hours following induced SAH. After the first few hours, increased respiration frequency (tachypnea) and decreased respiration amplitude $(30 \pm 8 \%)$, reduced inspiration and extended expiration time, apnea-tachypnea attack, diaphragmatic breath and, finally, respiration arrest were observed.

Figure 1 illustrates the macroscopic appearance of the brain of a deceased SAH animal; Figure 2 illustrates normal vagal nerve roots. In histopathological examination of the vagal nerve, axonal and periaxonal thinning, axonal loss and expanded interaxonal space were accepted as axonal degeneration criteria. Also, in animals that died prior to the end of the 20day observation period, decreased darkening points were

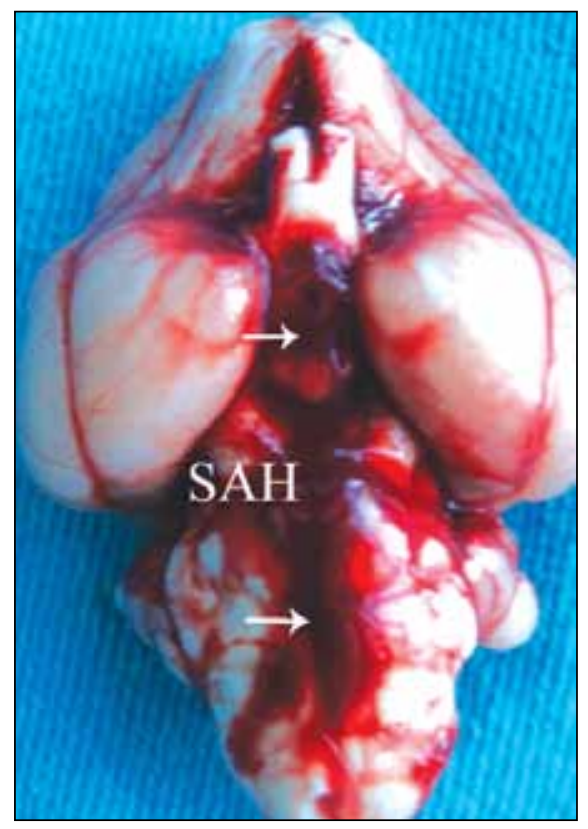

Figure 1: Basal view of a brain with SAH created animal. considered evidence of axonal injury. These changes in the vagal nerves were observed more often in animals that died than in those that lived for the 20 days of observation (Figures $3,4)$. Normal respiration rate was $30 \pm 6 \mathrm{bpm}$. Stereological examinations revealed a normal axon density of vagal nerves of $28500 \pm 5500$ in both the normal control animals and the SHAM group, whereas mean axon density was $22250 \pm 3500$ in survivors and $16450 \pm 2750$ in dead SAH animals. The severity of axonal degeneration of vagal nerves was greater in the dead SAH animals $(16750 \pm 4750)$ than in the survivors $(5700 \pm 750) \quad(p<0.0001)$. Respiration capacity and depth are summarized in Figure 5. There was a linear relationship between the respiration variables and the degree of axonal injury of vagal nerves.

With regard to the respiration parameters and histopathological changes of the vagal nerves observed, degenerated axons were more prominent in animals that developed high

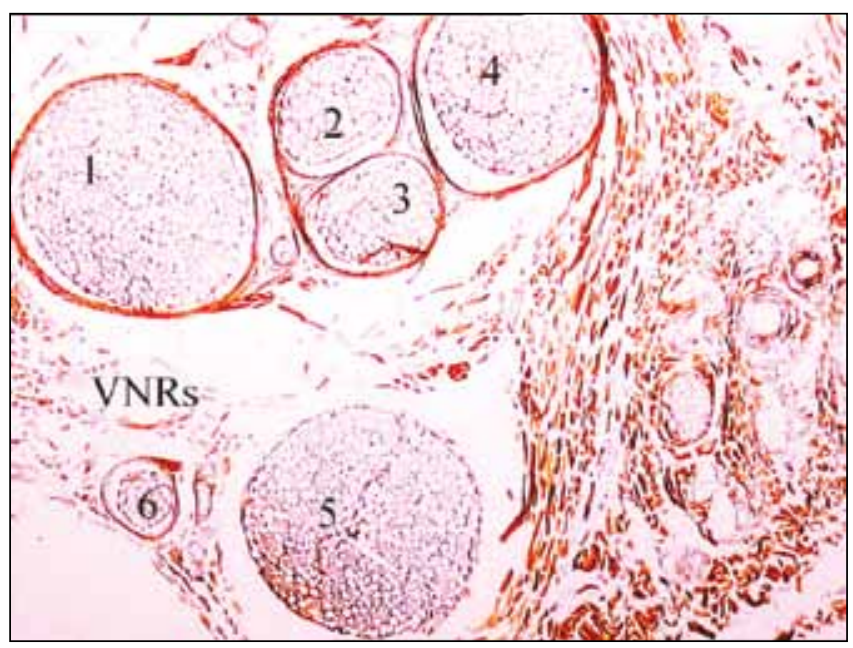

Figure 2: Vagal nerve roots just over the jugular foramen (LM, S-100, x 20).

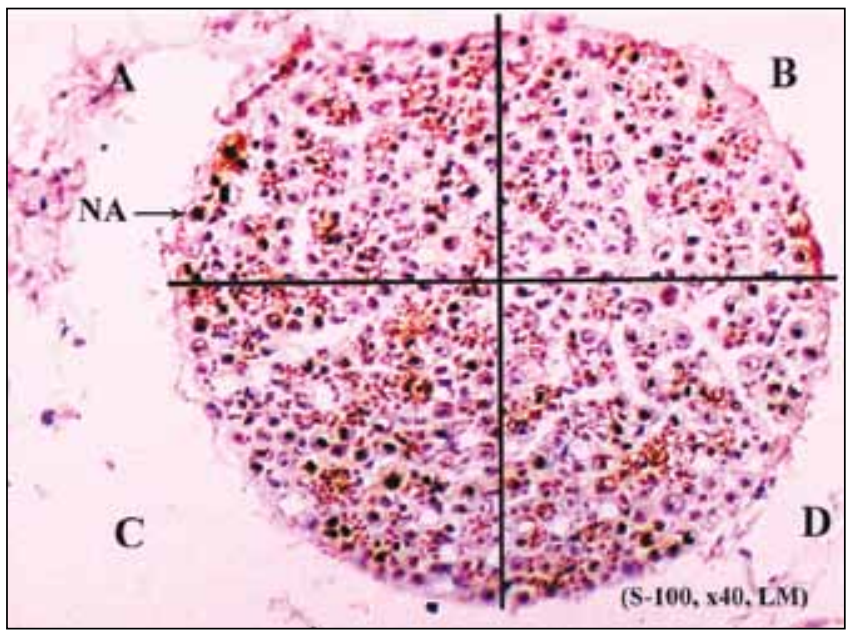

Figure 3: Transverse section of a visceromotor branch of vagal nerve root at the brainstem level of a normal rabbit (NA-Normal axon of vagal nerve) (LM, S-100, x 40). 
frequency tachycardia than those with low frequency tachycardia. Also, animals that displayed respiration irregularity and arrest had more mechanical lesions of nerve roots and degenerated axons in their vagal nerves.

\section{DISCUSSION}

In fatal $\mathrm{SAH}$, respiration muscles are paralyzed and breathing reflexes are broken down due to ischemic insult of vagal nerve and other lower cranial and upper cervical nerve injuries, increased intracranial pressure and mechanical consequences of brain stem herniation (11). Autonomic innervation of respiratory organs is sustained by branches from the vagal nerves and the lower four cervical and

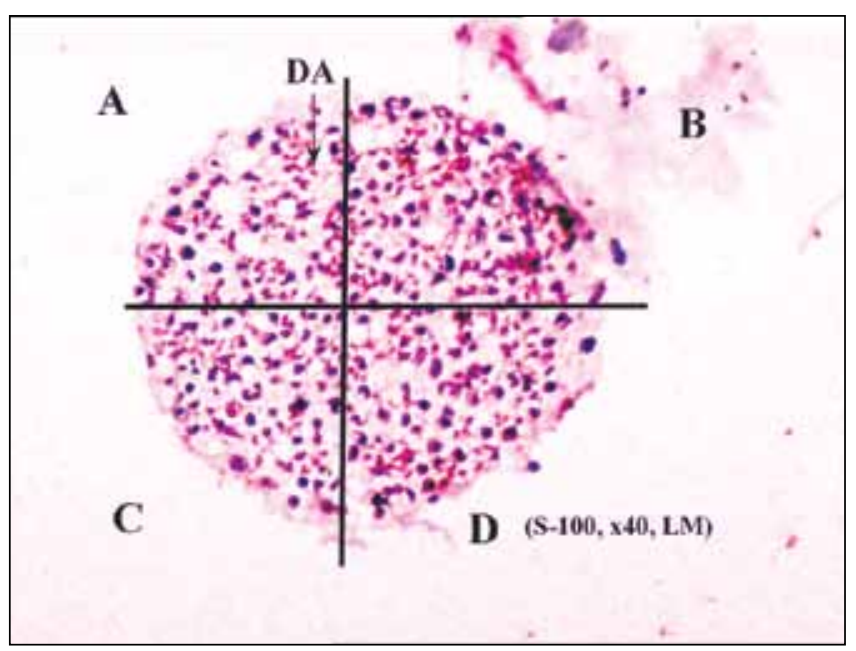

Figure 4: Transverse section of a thinned visceromotor branch of vagal nerve root at the brainstem level of a dead rabbit (NANormal axon of vagal nerve) (LM, S-100, x 40). upper five thoracic sympathetic ganglia. Preganglionic parasympathetic fibers travel through the pulmonary plexus and terminate in ganglia situated along the course of conducting airways. The ganglia are composed of excitatory cholinergic neurons and inhibitory noradrenergic neurons. Parasympathetic innervation seems to predominate over sympathetic innervation (3). Sensory afferent fibers are also present in the autonomic and somatic nerve plexuses. The somatic sensitive-motor nerves surround the respiration muscles, pleural and thoracic surfaces. The parasympathetic system plays a major role in the continuation of spontaneous respiration. Sympathetic nerve fibers lie within the walls of pulmonary artery branches, but the parasympathetic nerves associated with pulmonary circulation is less well known and probably less extensive (12). We investigated the role of the injured vagal nerve on respiration rhythm disorders associated with SAH. We showed that axonal injury occurred in the vagal nerves on radicular levels.

All autonomic and somatic nerves control the caliber of the conducting airways and pulmonary blood vessels, the volume of respiratory units, the activity of bronchial glands and respiration reflexes. Pulmonary-based reflexes are maintained primarily by vagal nerves (4). Together, the vagal and spinal sensory fibers and sympathetic fibers form the pulmonary plexus, and these regulate lung functions via microganglia. Microganglia are associated with the plexus and the peripheral ends of the vagal nerve branches in the larynx, epiglottis, trachea, bronchi, blood vessels, smooth muscles of airways, the submucosa and the secretory cells (24). The vagal nerve is the principle neural pathway that interconnects the brainstem and the lungs. The vagal nerve is involved in both central respiration rhythm and the regulation of pulmonary

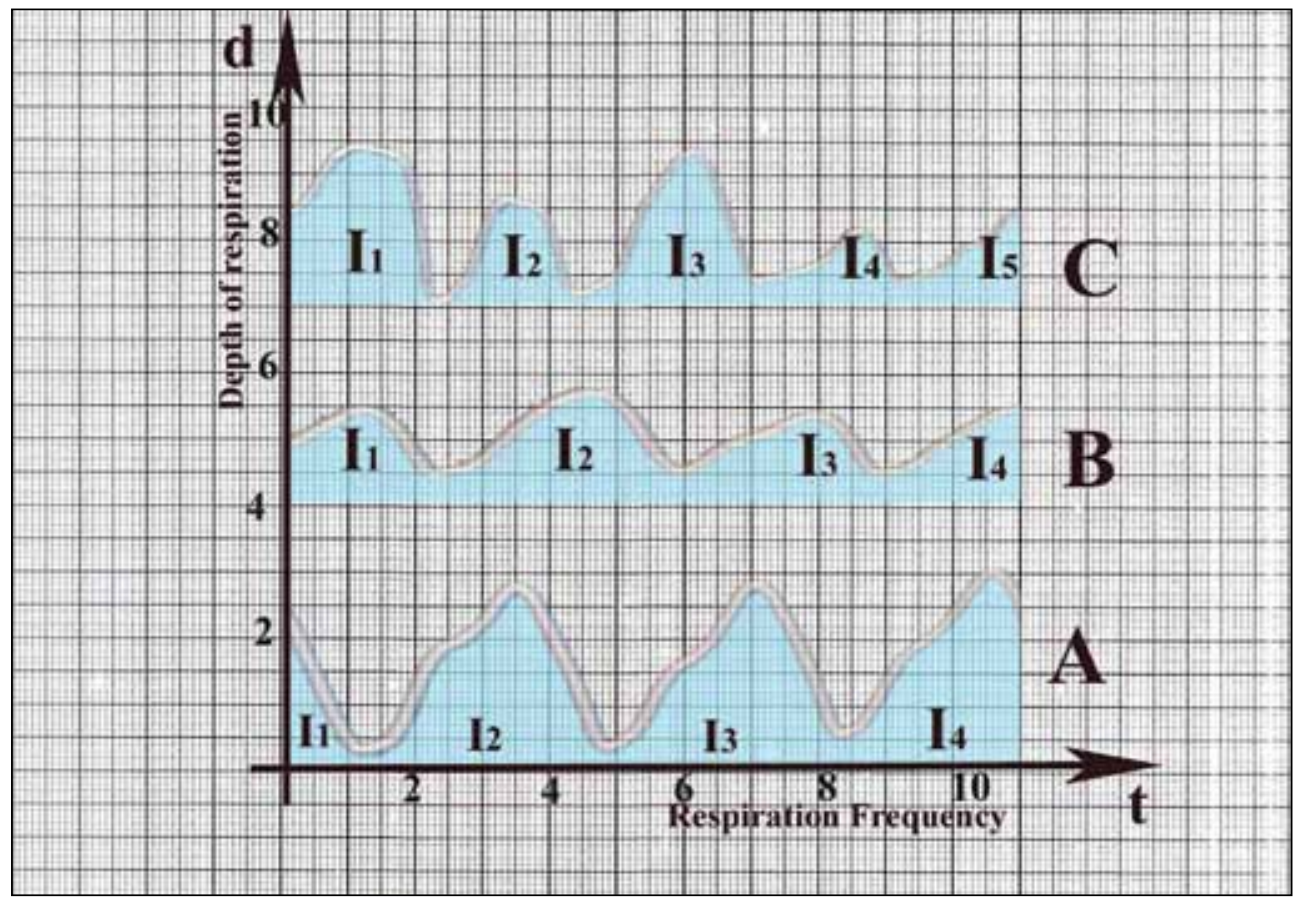

Figure 5: Schematic representation of respirationtime curve showing that the respiration depths (d) and inspiration capacities of all groups $(11,2,3, \ldots \mathrm{n})$. The height of the curves from basal line to the apical points accepted as respiration depth and the surface covered by curve and basal line accepted as respiration capacity per respiration cycles recorded during two seconds. Then, these values multiplied with 30 for the calculation of the mean values of per minutes. The A curve belong to normal animals, The $B$ curve belong to survivors and the $C$ curve belong to dead animals. 
vasculature, airways and pulmonary secretion (8). The immunoregulatory role of the vagal nerve on the lungs may be damaged secondary to vagal nerve injury, and respiration rhythm may be disordered because of lung inflammation (9).

Activation of the pulmonary stretch receptors by lung inflation or vagal stimulation evokes the Hering-Breuer reflex, which is characterized by inspiratory inhibition and expiratory prolongation (13). Long duration stimulation of the vagus nerve produced a classic Hering Breuer reflex characterized by the inhibition of inspiration and the facilitation of inspiration. High frequency stimulation of the central end of the vagus nerve induces a shortening of the inspiratory phase and lengthening of the expiratory phase (25). Vagal nerve stimulation also induces bronchoconstriction (12). Another important cause of breath disability associated with the beginning of $\mathrm{SAH}$ is bronchoconstriction due to ischemic vagal discharge. Bilateral vagus nerve stimulation for 30 seconds causes bronchoconstriction and respiration rhythm disorders characterized by apneustic attacks (18). So, ischemic vagal discharge resembling vagal stimulation may be considered as a triggering factor in apneustic attacks at the beginning of SAH.

The centrally generated respiratory rhythm is under strong modulation by peripheral information, such as that from the slowly adapting pulmonary stretch receptors conveyed via the vagus nerve (23). Irritant receptors are rapidly adapting receptors and localized mainly in extrapulmonary airways. They are stimulated by irritative mechanical and chemical stimuli that produce bronchospasm (15). Irritant receptors play a major role in breath rhythm regulation in critical situations by causing bronchial and tracheal constriction, rapid shallow breathing, and a decrease in the heart rate (5). All afferent nerve fibers to the central nervous system from receptors in the lungs and airways travel in the vagus nerve. Most of the afferent fibers innervating the lungs are conveyed via vagal nerves. Impulses of chemoreceptors are conveyed by glossopharyngeal and vagal nerve fibers to the respiration centers (17). Skeletal muscle proprioceptors of somatosensitive nerves play a major role in the conscious continuation of respiration (21). When respiration units are deformed by chemical, pathophysiologic or mechanical factors, these neural networks initiate the Hering-Breuer reflex and affect the pattern of breathing $(16,19)$.

Blockade of vagal nerves by capsaicin greatly reduces the frequency of spontaneous augmented breaths. Carotid sinus denervation diminishes both the frequency and amplitude of spontaneous augmented breaths (17). During the late phase of $\mathrm{SAH}$, irreversible axonal injury of the vagal nerve may mimic a blockade of vagal nerves. Respiratory sinus arrhythmia occurs mainly due to inhibition of cardioinhibitory parasympathetic cardiac vagal neurons during inspiration (2). Ryan et al. (22) showed that vagal nerve injury causes laryngopharyngeal muscle paralyses and tracheobronchial distortions. Distortion of the upper airway by negative transmural pressure causes reflex vagal bradycardia and bradypnea. This requires activation of cardiac vagal preganglionic neurons, which exhibit postinspiratory discharge (22).

In subarachnoid hemorrhage, the arteries of the vagal nerve roots are affected by vasospasm-generated mechanisms. Vagal reactivity predominantly regulates the resistance of peripheral airways during inspiration (6). The HeringBreuer reflex may be abolished during acutely developed cerebral ischemia and restored by recovery of ischemic cerebral processes $(1,20)$. In the present study, it is shown that $\mathrm{SAH}$ causes not only cerebral ischemic insult, but also brainstem and cranial nerve injuries. We hypothesized that ischemic vagal nerve root injury is an important factor in the development of respiratory arrhythmia. We demonstrated that subarachnoid hemorrhage may result in histopathologic ischemic changes, an observation not previously reported.

We have got some limitations. First, the devices such as ECG and monitor we used were designed for human patients. Thus, although we have used them in the setting of new borns, there may be measurement mistakes due to mismatch. Second, we did not evaluate injury in respect to the duration and severity of SAH. Third, this is an animal study, thus the results cannot be generalized to human patient. It is better to conduct a study evaluating the effect of SAH on vagal nerves in postmortem $\mathrm{SAH}$ patients.

\section{CONCLUSION}

it is well known that the vagal nerves play many important role on the continuation of respiration, such as regulation of airways and pulmonary vessel resistance, pulmonary pressure, the Hering-Breuer reflex, blood $\mathrm{pH}$, respiration and heart rhythm coordination, lung metabolism and immunity. In subarachnoid hemorrhage, vagal nerve root injury causes corruption of efferent and afferent vagal reflexes, which leads to a breakdown in the regulation of respiration mechanisms. Ultimately, these pathologic processes cause respiration arrest and death.

\section{REFERENCES}

1. Aydin MD, Ozkan U, Gündoğdu C, Onder A: Protective effect of posterior cerebral circulation on carotid body ischemia. Acta Neurochir 144:369-372, 2002

2. Bouairi E, Neff R, Evans C, Gold A, Andresen MC, Mendelowitz D: Respiratory sinus arrhythmia in freely moving and anesthetized rats. J Appl Physiol 97:1431-1436, 2004

3. Cohhen MI: Neurogenesis of respiratory rhythm in the mammal. Physiol Rev 59:1105-1173, 1979

4. Crapo JD, Barry BE, Gehr P, Bachofen M, Weibel ER: Cell number and cell characteristics of the normal human lung. Am Rev Respir Dis 126:332-337, 1982

5. Dehkordi O, Rose JE, Balan KV, Kc P, Millis RM, JayamTrouth A: Neuroanatomical relationships of substance P-immunoreactive intrapulmonary C-fibers and nicotinic cholinergic receptors. J Neurosci Res 87:1670-1678, 2009 
6. Fuller SD, Freed AN: Partitioning of pulmonary function in rabbits during cholinergic stimulation. J Appl Physiol 78:1242-1249, 1995

7. Gail DB, Lenfant CJM: Cells of the lung: Biology and clinical implications. Am Rev Respir Dis 127:366-387, 1983

8. Gaspari RJ, Paydarfar D: Respiratory failure induced by acute organophosphate poisoning in rats: Effects of vagotomy. Neurotoxicology 30:298-304, 2009

9. Goehler LE, Erisir A, Gaykema RP: Neural-immune interface in the rat area postrema. Neuroscience 140:1415-1434, 2006

10. Gundersen HJ, Bendtsen TF, Korbo L, Marcussen N, Møller A, Nielsen K, Nyengaard JR, Pakkenberg B, Sørensen FB, Vesterby A: Some new, simple and efficient stereological methods and their use in pathological research and diagnosis. APMIS 96:379-394, 1988

11. Hawkins TD, Sims C, Hanka R: Subarachnoid haemorrhage of unkown cause: a long-term follow-up. J Neurol Neurosurg Psychiatry 52:230-235, 1989

12. Lama A, Delpierre S, Jammes Y: The effects of electrical stimulation of myelinated and non-myelinated vagal motor fibres on airway tone in the rabbit and the cat. Respir Physiol 74:265-274, 1988

13. Li Y, Song G, Cao Y, Wang H, Wang G, Yu S, Zhang H: Modulation of the Hering-Breuer reflex by raphe pallidus in rabbits. Neurosci Lett 397:259-262, 2006

14. Licursi de Alcântara AC, Salgado HC, Sassoli Fazan VP: Morphology and morphometry of the vagus nerve in male and female spontaneously hypertensive rats. Brain Res 1197:170-180, 2008

15. Matsumoto S: The activities of lung stretch and irritant receptors during cough. Neurosci Lett 19:125-129, 1988
16. Matsumoto S: Effects of vagal stimulation on slowly adapting pulmonary stretch receptors and lung mechanics in anesthetized rabbits. Lung 174:333-344, 1996

17. Matsumoto S, Takeda M, Saiki C, Takahashi T, Ojima K: Effects of vagal and carotid chemoreceptor afferents on the frequency and pattern of spontaneous augmented breaths in rabbits. Lung 175:175-186, 1997

18. Matsumoto S: Low frequency-dependent mechanism of the $\mathrm{M} 2$ receptor function on vagally mediated bronchoconstriction in rabbits in vivo. Life Sci 65:103-112, 1999

19. Monier A, Burnet $H$, Jammes $Y$ : Hypoxemia does not affect the strength of the inspiration-inhibiting Breuer-Hering reflex. Neurosci Lett 197:129-132, 1995

20. Pluta R, Romaniuk JR: Recovery of breathing pattern after 15 min of cerebral ischemia in rabbits. J Appl Physiol 69:16761681,1990

21. Polgar G, Weng TR: The functional development of respiratory system from the period of gestation to adulthood. Am Rev Respir Dis 120:625-695, 1979

22. Ryan S, McNicholas WT, O'Regan RG, Nolan P: Effect of upper airway negative pressure and lung inflation on laryngeal motor unit activity in rabbit. J Appl Physiol 94:1307-1316, 2003

23. Takano K, Kato F: Inspiration-promoting vagal reflex in anaesthetized rabbits after rostral dorsolateral pons lesions. J Physiol 550:973-983, 2003

24. Taylor SM, Pare PD, Schellenberg RR: Cholinergic and nonadrenergic mechanisms in human and guinea-pig airways. J Appl Physiol 56:958-965, 1984

25. Wang GM, Song G, Zhang HP:Phenomenon of non-associative learning in Hering-Breuer reflex simulated by electrical vagal stimulation in rabbits. Sheng Li Xue Bao 57:511-516, 2005 